\title{
Potential of Controlled Irrigation and Drainage for Reducing Nitrogen Emission from Rice Paddies in Southern China
}

\author{
Guang-cheng Shao, ${ }^{1}$ Ming-hui Wang, ${ }^{1}$ Shuang-en Yu, ${ }^{1}$ Na Liu, ${ }^{2}$ \\ Meng-hua Xiao, ${ }^{1}$ and Min Yuan ${ }^{1}$ \\ ${ }^{1}$ Key Laboratory of Efficient Irrigation-Drainage and Agricultural Soil-Water Environment in Southern China, Ministry of Education, \\ College of Water Conservancy and Hydropower Engineering, Hohai University, Nanjing 210098, China \\ ${ }^{2}$ School of Economics and Management, Nanjing University of Information Science \& Technology, Nanjing 210044, China \\ Correspondence should be addressed to Guang-cheng Shao; sgclnszj@gmail.com
}

Received 11 December 2014; Revised 26 January 2015; Accepted 26 January 2015

Academic Editor: Jun Wu

Copyright (C) 2015 Guang-cheng Shao et al. This is an open access article distributed under the Creative Commons Attribution License, which permits unrestricted use, distribution, and reproduction in any medium, provided the original work is properly cited.

The effect of controlled irrigation and drainage (CID) at different growth stages of rice on nitrogen (N) from rice paddy was studied. Submergence at different stages was imposed in specially designed experimental tanks in 2009 and 2010 based on alternate wetting and drying technology (AWD, the control, CK). Treatments include CID treatment at tiller stage (T1), jointing-booting stage (T2), panicle initiation stage (T3), and milky stage (T4). Results showed that fertilization could significantly increase the concentration of $\mathrm{NH}_{4}{ }^{+}-\mathrm{N}$ and TN in surface water but had a little influence on $\mathrm{NO}_{3}{ }^{-}-\mathrm{N}$. The concentrations of $\mathrm{NH}_{4}{ }^{+}-\mathrm{N}^{-}$and $\mathrm{NO}_{3}{ }^{-}-\mathrm{N}_{\text {in }}$ surface water increased at first and then decreased after fertilization, while the concentrations of $\mathrm{NH}_{4}^{+}-\mathrm{N}$ and TN in groundwater kept on being relatively stable. Compared to CK, CID significantly increased the concentration of $\mathrm{NH}_{4}^{+}-\mathrm{N}$ in surface water at four stages. However, it reduced the concentration of $\mathrm{NO}_{3}{ }^{-}-\mathrm{N}$. Consistent with the reduction of drainage, $\mathrm{CID}$ at four stages could significantly decrease the amount of $\mathrm{NH}_{4}{ }^{+}-\mathrm{N}$ and $\mathrm{NO}_{3}{ }^{-}-\mathrm{N}$ losses by runoff in relation to $\mathrm{CK}$.

\section{Instruction}

Rice (Oryza sativa L.) is the staple food for the population that lives in China. The rice season in Southern China coincides with the summer wet season and the annual average precipitation is more than $1000 \mathrm{~mm}$. Drainage is an important measure to allow timely field operation and protect field rice from waterlogging. However, irrational drainage shortens the residence time of water in the biologically active unsaturated zone and substantially alters the water regime. This results in an increase in nitrate losses from the agricultural fields to surface recipients $[1,2]$. Moreover, the excessive use of the $\mathrm{N}$ fertilizers has also accelerated the loss of $\mathrm{N}$ entering ambient water bodies through various means [3]. In a paddyirrigation district, the quantity and quality of drainage water are primarily controlled by irrigation and fertilization activities, and transport of non-point-source pollution is largely dependent on the drainage process [4].

Decreasing water availability for agriculture threatens irrigated rice productivity, and ways must be sought to reduce irrigation water demands while maintaining grain yield of rice [5-7]. Several water-saving technologies such as alternate wetting and drying (AWD) and aerobic rice are being developed to lower the water requirements of rice crop [6]. Attempts to reduce nutrient losses in drainage water have led to the development of controlled drainage. Controlled irrigation and drainage (CID) aims to take advantage of both alternate wetting and drying and controlled drainage. With CID, a higher water depth is maintained and more drainage water is captured during rain events than with AWD. Under this water management practice, more surface runoff is captured in paddy field for later use during moisture deficit periods. When CID was imposed on rice plants at different stages, they experience two environmental changes: the change from aerobic to anaerobic conditions and the subsequent change from anaerobic to aerobic conditions when the floodwater recedes [8]. The resultant soil-water atmosphere system is highly complex and heterogeneous in nature [9]. Soil under CID at the time of crop growth can trigger several physicochemical and microbiological processes. The behavior of 
nitrogen under CID is markedly different from its behavior under AWD. Understanding the $\mathrm{N}$ change processes under CID would greatly facilitate regulating $\mathrm{N}$ losses from rice paddy and increase the availability of $\mathrm{N}$.

Under CID conditions, a higher water depth is maintained, resulting in an increase in soil moisture, which was more conducive to microbial denitrification [10]. Ammoniacal $\mathrm{N}$ is subject to fixation by clays, loss by volatilization leaching, runoff, seepage, and nitrification followed by loss through denitrification. In flooded paddy soils, after trapped molecular oxygen $\left(\mathrm{O}_{2}\right)$ has been quickly consumed, sequential reduction of the following soil oxidants progresses in accordance with thermodynamic theory: nitrate $\left(\mathrm{NO}_{3}{ }^{-}\right)$, manganese (IV) $\left(\mathrm{Mn}_{4}{ }^{+}\right)$, ferric iron $\left(\mathrm{Fe}^{3+}\right)$, sulfate $\left(\mathrm{SO}_{4}{ }^{2-}\right)$, and $\mathrm{CO}_{2}$ [11]. Partly submergence can result in the accumulation of $\mathrm{NH}_{4}{ }^{+}-\mathrm{N}$, the instability of $\mathrm{NO}_{3}{ }^{-}-\mathrm{N}$, and a lowered $\mathrm{N}$ requirement for organic matter decomposition. Studies demonstrated significant reductions of nitrate in drainage water discharged from controlled drainage systems as a result of reduced drainage flow and lower concentrations in the shallow groundwater [12]. Field data and modeling with Hydrus-2D by Hesterberg et al. [13] have shown how the composition of the drainage water varies as a result of changes in the flow pattern associated with transient water tables and variation in concentrations with depth in the soil profile. Huang et al. [14] showed that agricultural loss of nitrogen and cumulative runoff were positively related through the indoor rainfall simulation test. Wesström and Messing [15] reported $79 \%$ and $94 \%$ reductions in drain outflows for successive years following controlled drainage implementation. These outflows significantly reduced $\mathrm{N}$ and nitrate $\left(\mathrm{NO}_{3}{ }^{-}-\mathrm{N}\right)$ losses. In North Carolina, several studies showed that controlled drainage can decrease drain outflow volumes and annual nitrogen (N) [16]. Similarly Lalonde et al. [12] showed drain flow and $\mathrm{NO}_{3}{ }^{-}-\mathrm{N}$ reductions for variable riser heights of 58$63 \%$ and $69-76 \%$, respectively.

Based on the understanding of $\mathrm{N}$ transformation processes, water level management can be developed to minimize fertilizer and water $\mathrm{N}$ loss and increase efficiency of this important nutrient element in Southern China. Here, we presented field measurements of $\mathrm{N}$ from rice paddy under controlled irrigation and drainage in Southern China in 2009 and 2010. The main objectives of this study are to gain an insight into a complete accounting of nitrogen change from rice paddy under CID and thereby to examine if CID could be an effective option for mitigating environmental pollution. We hypothesize that plots have the same seepage and percolation rates when a water table existed at the soil surface, and water table recession occurs evenly when floodwater recedes.

\section{Experimental Design and Methods}

2.1. Experimental Site and the Soil Properties. The experiments were conducted in specially designed experimental tanks at the Key Laboratory of Efficient Irrigation-Drainage and Agricultural Soil-Water Environment in Southern China, Ministry of Education (Nanjing, latitude $31^{\circ} 57^{\prime} \mathrm{N}$, longitude $118^{\circ} 50^{\prime} \mathrm{E}$, and $144 \mathrm{~m}$ above sea level), during the rice growing seasons (May to October) of 2009 and 2010. The region has a subtropical humid monsoon climate, with the average annual evaporation of $900 \mathrm{~mm}$ and annual mean temperature of $15.4^{\circ} \mathrm{C}$, and the maximum and minimum air temperatures are $43.0^{\circ} \mathrm{C}$ and $-14.0^{\circ} \mathrm{C}$, respectively. The mean annual rainfall from 1951 to 2009 is $1,051 \mathrm{~mm}$, where more than $60 \%$ of precipitation falls in the rainy season and the precipitation is concentrated in the months of May-September. The frostfree period is 220 days per year. The soil in the area is a typical permeable paddy soil, formed on loess deposits, with loamy clay. There are 15 fixed tanks plots with specifications for the length $\times$ width $\times$ depth $=2.5 \mathrm{~m} \times 2 \mathrm{~m} \times 2 \mathrm{~m}$. The irrigation system is automatic irrigation system controlled by the hostelectromagnetic valve. The soil $(0-30 \mathrm{~cm})$ in tanks with $\mathrm{pH}$ value of 6.97 contained $2.19 \%$ of soil organic matter, $0.91 \mathrm{~g} / \mathrm{kg}$ of total nitrogen, $27.65 \mathrm{mg} / \mathrm{kg}$ of available nitrogen, $0.32 \mathrm{~g} / \mathrm{kg}$ of total phosphorus, and $12.5 \mathrm{mg} / \mathrm{kg}$ of available phosphorus.

2.2. Experimental Design. The paddy tanks were $2 \mathrm{~m}$ wide, $2.5 \mathrm{~m}$ long, and $2 \mathrm{~m}$ high containers constructed from concrete block and sealed with a waterproof paint (Figure 1). PVC pipe connected supply and drainage holes in the tanks to $3 \mathrm{~m}$ high bottles, which were connected with a tank that supplied water. The bottom of each tank was filled with a $20 \mathrm{~cm}$ layer of coarse gravel, separated from the soil by a water-permeable membrane to allow free supply and drainage. When rainfall increased water depth beyond the upper designated water level, drainage occurred. Groundwater level was changed by raising or lowering the height of the float valve that controlled the solenoid valve for each treatment (Figure 1). When the ponded water depth dropped to the lower water level, irrigation water was added with autoirrigation system until the upper water table limit was reached. Five treatments were used to evaluate the effects of CID at four stages on the change of concentration of $\mathrm{N}$ during the 2009 and 2010 experiments (Table 1). The tank water depth of AWD treatment was kept between $-200 \mathrm{~mm}$ and $20 \mathrm{~mm}$ from the soil surface (the control) at tillering stage and between $-300 \mathrm{~mm}$ and $30 \mathrm{~mm}$ at other stages. Two levels of ponded water depth were applied for 10 days at tillering stage, jointing-booting stage, and panicle initiation stage, plus for $14 \mathrm{~d}$ at milky stage.

2.3. Plant Material and Cultivated Practices. Yangjing 4038, high-yielding rice currently used in local production, was grown in the paddy tanks. Seedlings were raised in a seedbed and sowing dates were May 11, 2009, and May 15, 2010. Seedlings were transplanted on June 14, 2009, and June 29, 2010 , at a hill spacing of $0.25 \mathrm{~m} \times 0.20 \mathrm{~m}$, with three seedlings per hill. A week before transplanting, the experimental plots were dry-ploughed and harrowed. The soil was soaked 1 day before transplanting and then flooded for about 1 week with a $2-3 \mathrm{~cm}$ water layer to promote good crop establishment. Applications of fertilizer $\left(\mathrm{N}-\mathrm{P}_{2} \mathrm{O}_{5}-\mathrm{K}_{2} \mathrm{O}, 15: 15: 15\right)$ at the rate of $1,200 \mathrm{~kg} / \mathrm{ha}$ in the form of compound fertilizer were applied in three equal splits. Plants were harvested on October 23, 2009, and October 29, 2010. All other recommended cultivated practices for achieving maximum grain yield were followed. 


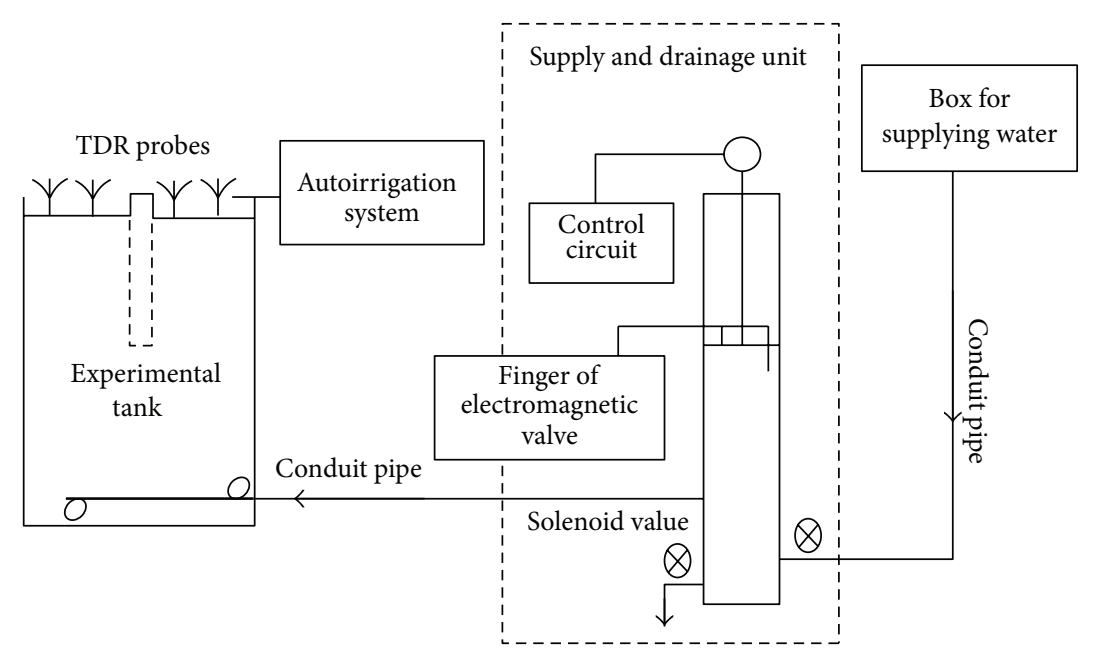

FIGURE 1: Schematic diagram of the experimental set-up placed in the tank.

TABLE 1: Design of controlled irrigation and drainage (CID) scheduling.

\begin{tabular}{lcccr}
\hline Treatments & Tillering stage & Jointing-booting stage & Panicle initiation stage & Milky stage \\
\hline T1 & $120 \mathrm{~mm}(10 \mathrm{~d})$ & $-300 \mathrm{~mm} \sim 30 \mathrm{~mm}$ & $-300 \mathrm{~mm} \sim 30 \mathrm{~mm}$ & $-300 \mathrm{~mm} \sim 30 \mathrm{~mm}$ \\
T2 & $-200 \mathrm{~mm} \sim 20 \mathrm{~mm}$ & $250 \mathrm{~mm}(10 \mathrm{~d})$ & $-300 \mathrm{~mm} \sim 30 \mathrm{~mm}$ & $-300 \mathrm{~mm} \sim 30 \mathrm{~mm}$ \\
T3 & $-200 \mathrm{~mm} \sim 20 \mathrm{~mm}$ & $-300 \mathrm{~mm} \sim 30 \mathrm{~mm}$ & $250 \mathrm{~mm}(10 \mathrm{~d})$ & $-300 \mathrm{~mm} \sim 30 \mathrm{~mm}$ \\
T4 & $-200 \mathrm{~mm} \sim 20 \mathrm{~mm}$ & $-300 \mathrm{~mm} \sim 30 \mathrm{~mm}$ & $-300 \mathrm{~mm} \sim 30 \mathrm{~mm}$ & $250 \mathrm{~mm}(14 \mathrm{~d})$ \\
CK & $-200 \mathrm{~mm} \sim 20 \mathrm{~mm}$ & $-300 \mathrm{~mm} \sim 30 \mathrm{~mm}$ & $-300 \mathrm{~mm} \sim 30 \mathrm{~mm}$ & $-300 \mathrm{~mm} \sim 30 \mathrm{~mm}$ \\
\hline
\end{tabular}

Note: $-I \mathrm{~mm} \sim J \mathrm{~mm}$ denotes that water depth was kept between $-I \mathrm{~mm}$ and $J \mathrm{~mm}$ at four stages of paddy rice at normal time; when water level lowered to $-I \mathrm{~mm}$, irrigation water is added until water table reached $J \mathrm{~mm} . K \mathrm{~mm}(H \mathrm{~d})$ indicates that $K \mathrm{~mm}$ fixed water level was kept with duration of $H$ days at four stages of paddy rice from the soil surface. The allowable variation of fixed water level was $\pm 5 \mathrm{~mm}$ during the period of implementation. The maximum water height after rainfall for the control is $50 \mathrm{~mm}$ at the tillering stage and $100 \mathrm{~mm}$ at other stages. When rainfall increased water depth beyond the designed value, drainage occurs. $4 \mathrm{~mm}$ water leakage per day was kept when water table existed at soil surface. AWD indicates alternate wetting and drying irrigation; CID-Stage I, CID-Stage II, CID-Stage III, and CID-Stage IV denote the CID treatments at tillering stage (Stage I), jointing-booting stage (Stage II), panicle initiation stage (Stage III), and milky stage (Stage IV), respectively.

2.4. Sample Collection and Measurement. Field water depth was observed at 9 o'clock by ruler. When the minimum level was reached, the autoirrigation system would irrigate until water level reached maximum level. Similarly, when water level exceeded maximum level due to rainfall, the drainage volume was subsequently calculated by counting the number of solenoid valves opened and stored by a datalogger. Water samples were collected in the polyethylene bottle for four times during the submergence period. The surface water was collected by the $50 \mathrm{~mL}$ syringe (without disturbing the soil and selecting the top surface water randomly); rinse all bottles firstly, and then take the appropriate amount of water sample. The subsurface water was collected by the underground drainage pipe. The water samples were analyzed for ammonium nitrogen $\left(\mathrm{NH}_{4}{ }^{+}-\mathrm{N}\right)$ and nitrate nitrogen $\left(\mathrm{NO}_{3}{ }^{-}-\mathrm{N}\right)$ by using a Shimadzu UV-2800 spectrophotometer. In accordance with "water and wastewater monitoring and analysis methods," alkaline per sulfate digestion and Nessler's reagent colorimetric phenol disulfonic acid spectrophotometer were used to analyze total nitrogen in water test (TN), ammonia $\left(\mathrm{NH}_{4}{ }^{+}-\mathrm{N}\right)$, and nitrate $\left(\mathrm{NO}_{3}{ }^{-}-\mathrm{N}\right)$ content. The $\mathrm{N}$ loss through runoff was calculated as the product of $\mathrm{NH}_{4}{ }^{+}-\mathrm{N}$ and $\mathrm{NO}_{3}{ }^{-}-\mathrm{N}$ concentration in runoff and the amount of runoff.
2.5. Statistical Analysis. We used a randomized complete block design with three replications. Treatment effects were analyzed using analysis of variance (ANOVA) procedure of SPSS software version 14.0. Treatment means were separated by least significant difference (LSD) test at $P \leq 0.05$, unless otherwise specified.

\section{Results}

3.1. The Change of the Concentration of $\mathrm{NH}_{4}{ }^{+}-\mathrm{N}, \mathrm{NO}_{3}{ }^{-}-\mathrm{N}$, and TN after Fertilization. Concentrations of $\mathrm{NH}_{4}{ }^{+}-\mathrm{N}$ and $\mathrm{NO}_{3}{ }^{-}-\mathrm{N}$ and $\mathrm{TN}$ in surface water and groundwater were measured after fertilization application from tillering to jointingbooting stage in 2009 and 2010 (Figure 2 and Table 2). After fertilization application at tillering stage, the highest concentration of $\mathrm{NH}_{4}{ }^{+}-\mathrm{N}$ in surface water was obtained on the second day, while for $\mathrm{NO}_{3}{ }^{-}-\mathrm{N}$ the highest concentration was observed on the third day (Figures 2(a)-2(d)). The average concentration of $\mathrm{NH}_{4}{ }^{+}-\mathrm{N}$ and $\mathrm{NO}_{3}{ }^{-}-\mathrm{N}$ in the surface water of paddy decreased dramatically after 7 days of submergence. Generally, the high rates of $\mathrm{N}$ application generally resulted in high concentrations of TN in the surface water, especially 

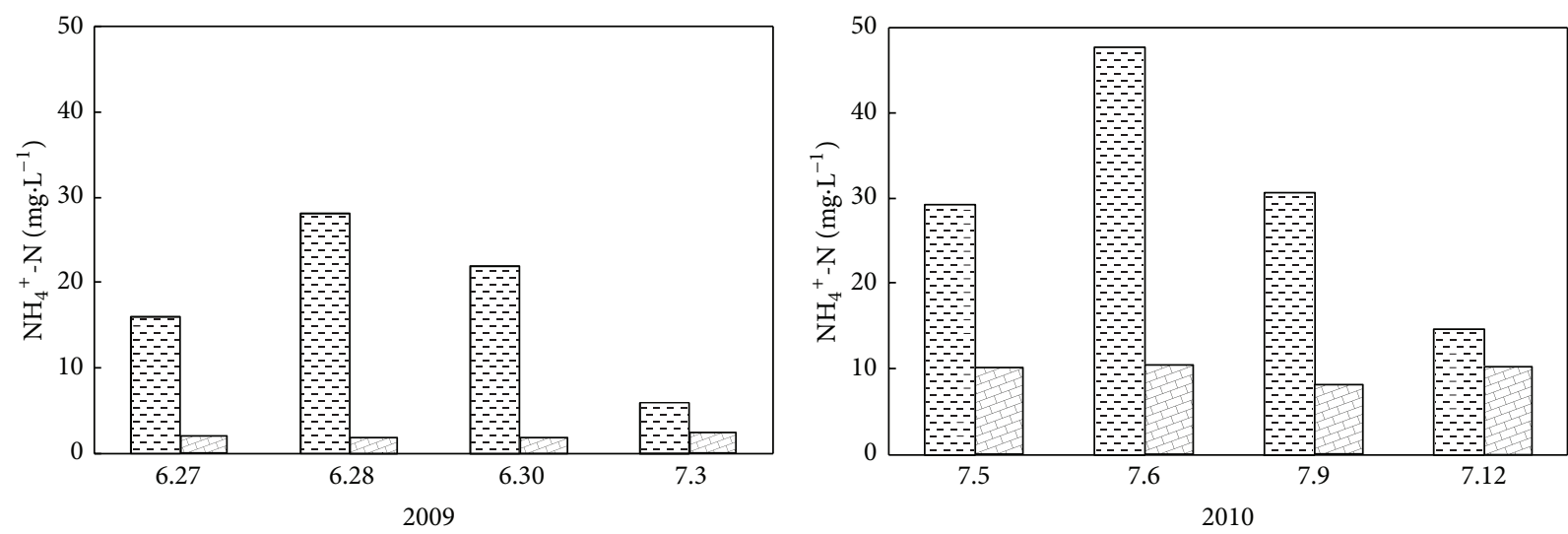

$\boxminus$ Surface
曰 Underground

国 Surface

国 Underground

(a)
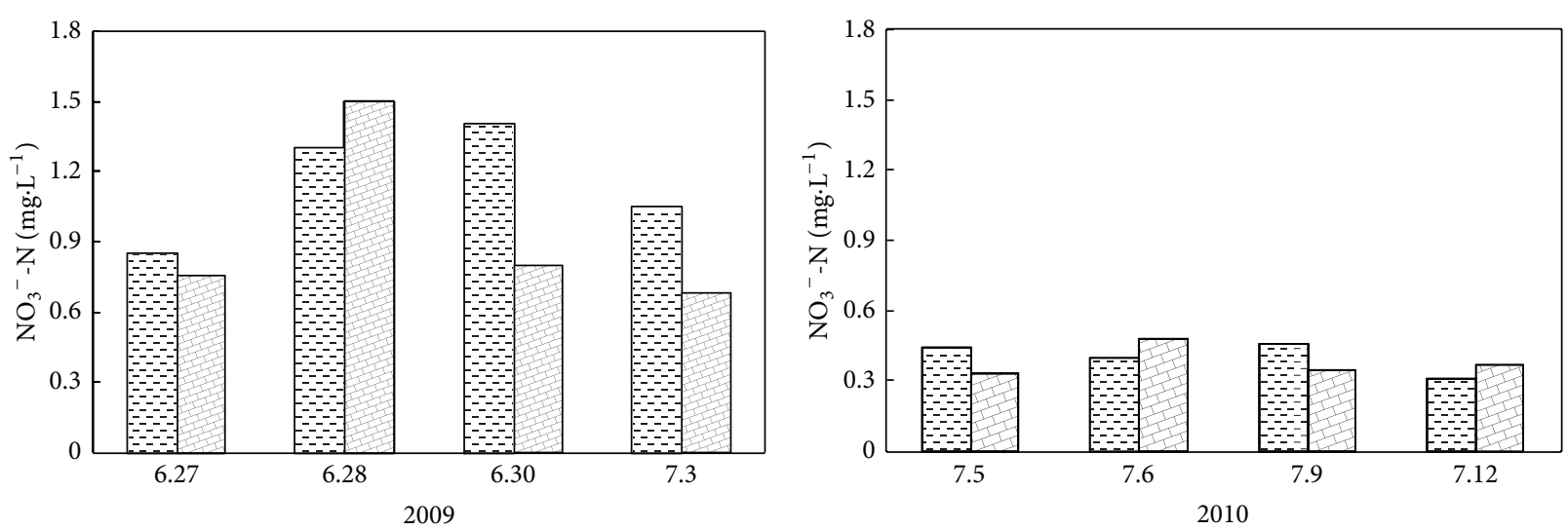

$\boxminus$ Surface

图 Underground

曰

国 Underground

(c)

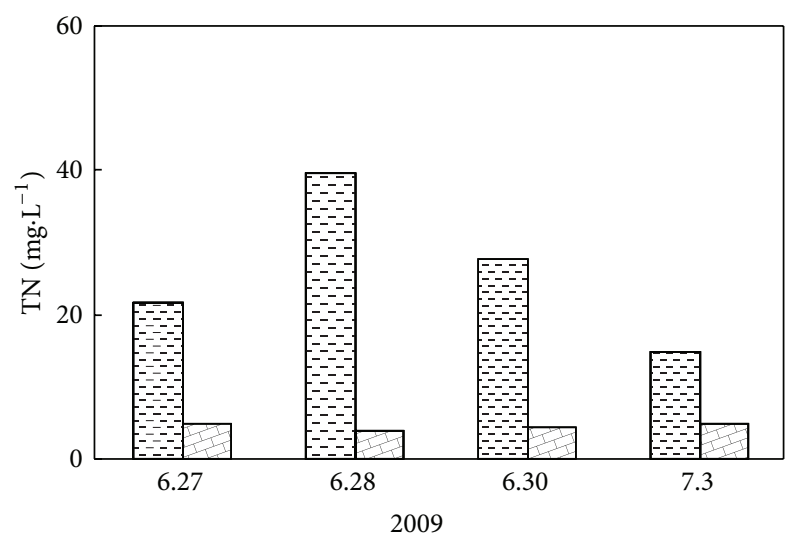

븐 Surface

目 Underground

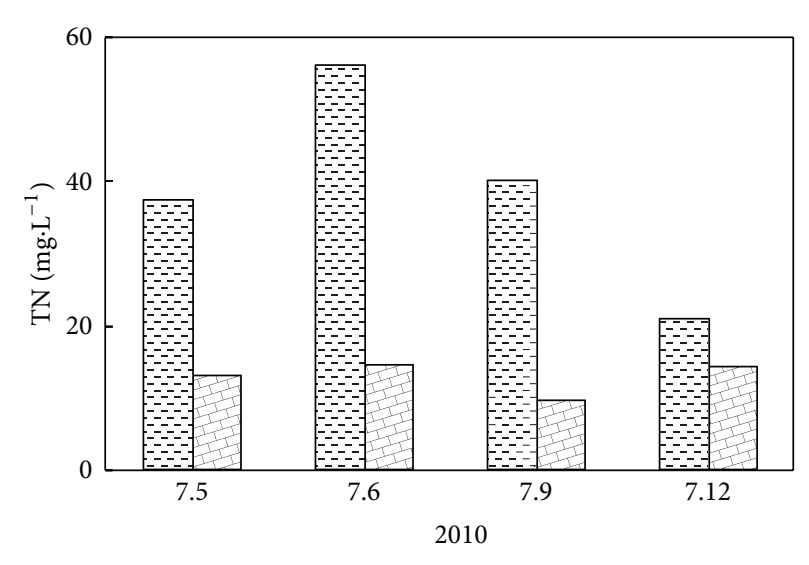

曰 Surface

田 Underground

(e)

(f)

FIgURE 2: The change of the concentration of $\mathrm{NH}_{4}{ }^{+}-\mathrm{N} \mathrm{NO}_{3}{ }^{-}-\mathrm{N}$, and $\mathrm{TN}$ after fertilization at tillering stage in 2009 and 2010. 
TABLE 2: The change of the concentration of $\mathrm{NH}_{4}{ }^{+}-\mathrm{N}, \mathrm{NO}_{3}{ }^{-} \mathrm{N}$, and TN after fertilization at tillering stage in 2010.

\begin{tabular}{lccccc}
\hline \multirow{2}{*}{ Form of N } & Sample site & \multicolumn{4}{c}{ Measure time } \\
& & 8.6 & 8.9 & 8.11 & 8.13 \\
\hline \multirow{2}{*}{$\mathrm{NH}_{4}{ }^{+}-\mathrm{N}(\mathrm{mg} / \mathrm{L})$} & Surface & 1.55 & 2.01 & 1.10 & 1.53 \\
& Underground & 0.74 & 0.56 & 2.09 & 0.77 \\
\hline \multirow{2}{*}{$\mathrm{NO}_{3}{ }^{-}-\mathrm{N}(\mathrm{mg} / \mathrm{L})$} & Surface & 0.28 & 0.41 & 0.28 & 0.25 \\
& Underground & 0.29 & 0.19 & 0.31 & 0.17 \\
\hline \multirow{2}{*}{$\mathrm{TN}(\mathrm{mg} / \mathrm{L})$} & Surface & 2.64 & 2.92 & 3.77 & 2.41 \\
& Underground & 2.62 & 2.39 & 2.46 & 2.84 \\
\hline
\end{tabular}

within 7 days after $\mathrm{N}$ application, which showed the increasing potential of $\mathrm{N}$ loss by runoff (Figures 2(e)-2(f)). The concentration of $\mathrm{NH}_{4}{ }^{+}-\mathrm{N}$ and $\mathrm{TN}$ in underground water showed more stability than those in surface water after fertilizer application. The concentration of $\mathrm{NO}_{3}{ }^{-}-\mathrm{N}$ in underground water reached the maximum on the second day and then decline with time passing. During the period of jointingbooting, the highest concentrations of $\mathrm{NH}_{4}^{+}-\mathrm{N}^{+}$and $\mathrm{NO}_{3}{ }^{-}-\mathrm{N}$ in surface water were observed on the third day after applying fertilization, while for TN the highest concentration was obtained on the fifth day (Table 2). The difference between tillering and jointing-booting stages may be attributed to different absorption during crop growth and environmental factors. The change of concentration of $\mathrm{NH}_{4}{ }^{+}-\mathrm{N}$ and $\mathrm{NO}_{3}{ }^{-}-$ $\mathrm{N}$ in underground water demonstrated similar trend to the concentration of TN in surface water. The concentration of TN within 7 days after $\mathrm{N}$ application was not significantly different.

\subsection{The Change of Concentration of $\mathrm{NH}_{4}{ }^{+}-\mathrm{N}$ during Submer-} gence. The concentration of $\mathrm{NH}_{4}^{+}-\mathrm{N}$ under $\mathrm{CK}$ increased with the time of submergence and reaches the maximum at the tenth day at tillering stage (Figure 3(a)). The average concentration of $\mathrm{NH}_{4}{ }^{+}-\mathrm{N}$ under $\mathrm{T} 1$ was $400 \%$ higher than that under $\mathrm{CK}$ on the first day after submergence. The differences in the concentration of $\mathrm{NH}_{4}{ }^{+}-\mathrm{N}$ between $\mathrm{Tl}$ and $\mathrm{CK}$ were significant at four times' measurements. As is shown in Figure 3(b), the concentration of $\mathrm{NH}_{4}{ }^{+}-\mathrm{N}$ under CK and T2 demonstrated the decline trend with time going on. This is because the crop absorbed some $\mathrm{NH}_{4}{ }^{+}-\mathrm{N}$ during submergence and resulted in the gradual decline of the concentration of $\mathrm{NH}_{4}^{+}-\mathrm{N}$. There were not significant differences in the concentration of $\mathrm{NH}_{4}{ }^{+}-\mathrm{N}$ between $\mathrm{T} 2$ and $\mathrm{CK}$. The dynamitic changes of the concentration of $\mathrm{NH}_{4}{ }^{+}-\mathrm{N}$ at panicle initiation stage during submergence were showed in Figure 3(c). The concentration of $\mathrm{NH}_{4}{ }^{+}-\mathrm{N}$ under T3 and CK reached the maximum after 3-day submergence and then decreased as time goes on. T3 significantly increased the concentration of $\mathrm{NH}_{4}{ }^{+}-\mathrm{N}$ during the submergence compared to CK. During the submergence at milky stage, the concentrations of $\mathrm{NH}_{4}{ }^{+}-$ $\mathrm{N}$ under $\mathrm{CK}$ and $\mathrm{T} 4$ showed a trend of rise first and then fall (Figure 3(d)). Compared with CK, submergence at milky stage also significantly increased the concentration of $\mathrm{NH}_{4}{ }^{+}$$\mathrm{N}$.
3.3. The Change of Concentration of $\mathrm{NO}_{3}{ }^{-}-\mathrm{N}$ during Submergence. The dynamitic changes of $\mathrm{NO}_{3}{ }^{-} \mathrm{N}$ in surface water after submergence at four stages in 2010 were shown in Figure 4. Submergence at tillering stage increased the concentration of $\mathrm{NO}_{3}{ }^{-}-\mathrm{N}$, but the difference between $\mathrm{Tl}$ and CK was not significant (Figure 4(a)). The concentration of $\mathrm{NO}_{3}{ }^{-}-\mathrm{N}$ for $\mathrm{Tl}$ declined with prolonged submergence. The concentration of $\mathrm{NO}_{3}{ }^{-}-\mathrm{N}$ under $\mathrm{Tl}$ at the end of submergence decreased to $38 \%$ of that on the first day. The concentrations of $\mathrm{NO}_{3}{ }^{-}-\mathrm{N}$ at jointing-booting stage were averagely lower than that at tillering stage. It is because rice grew rapidly at jointing-booting stage and absorbed more nitrogen resulting in the reduction in the concentration of $\mathrm{NO}_{3}^{-}-\mathrm{N}$. Submergence at jointing-booting stage significantly reduced the concentration of $\mathrm{NO}_{3}{ }^{-}-\mathrm{N}$ (Figure 4(b)). As shown in Figure 4(c), $\mathrm{NO}_{3}{ }^{-}-\mathrm{N}$ concentrations under the treatment T3 were lower than those under $\mathrm{CK}$ treatment during the submergence except at the eighth day. The concentration of $\mathrm{NO}_{3}{ }^{-}-\mathrm{N}$ was not significantly decreased by submergence compared to CK. At milky stage, it was observed that the concentration of $\mathrm{NO}_{3}{ }^{-}$-N under $\mathrm{T} 4$ showed the trend of rise after first decline. This may be attributed to the decomposition of leaves submerged in water at milky stage. The differences in the concentration of $\mathrm{NO}_{3}{ }^{-}-\mathrm{N}$ between $\mathrm{T} 4$ and $\mathrm{CK}$ were significant (Figure 4(d)).

3.4. Potential of $\mathrm{NH}_{4}{ }^{+}-\mathrm{N}$ and $\mathrm{NO}_{3}^{-}-\mathrm{N}$ Loss by Runoff during Submergence. $\mathrm{NH}_{4}^{+}-\mathrm{N}$ and $\mathrm{NO}_{3}^{-}-\mathrm{N}$ losses by runoff in different treatments as influenced by submergence at different stages during the year of 2010 were presented in Table 3. As was the case with surface water, $\mathrm{NH}_{4}{ }^{+}-\mathrm{N}$ was the major component of $\mathrm{N}$ in runoff water. Regarding $\mathrm{NH}_{4}{ }^{+} \mathrm{N}^{-}$and $\mathrm{NO}_{3}{ }^{-}-\mathrm{N}$ loss by runoff at tillering stage, the amount was decreased by $76 \%$ and $83 \%$ by submergence (T1) as compared with the CK treatment, respectively. The $\mathrm{NH}_{4}{ }^{+}-\mathrm{N}$ loss under T2, T3, and T4 was only $24 \%, 53 \%$, and $12 \%$, respectively, of that under CK. CID at jointing-booting, panicle initiation, and milky stages also decreases the amount of $\mathrm{NO}_{3}{ }^{-}-\mathrm{N}$ loss by $91 \%, 91 \%$, and $85 \%$ in relation to $\mathrm{CK}$.

\section{Discussion}

The increased attention being paid to the loss of nitrate via agricultural drainage has led many to call for significant changes in both management of $\mathrm{N}$ fertilizer and management of agricultural drainage systems [17]. Overall, current agronomic guidelines, which are primarily based on crop response, may inadequately protect the water quality in Southern China [18]. Although positive results were obtained by applying AWD technology in rice fields, the drainage volume in AWD has been reported to be larger due to the excessive drainage requirement, which results in an increase in nitrate losses from the agricultural fields $[19,20]$. This can be partially addressed by the introduction of irrigation and drainage management. This then allows drainage design and management within the reasonable bounds expected for long-term nitrate control [21]. 


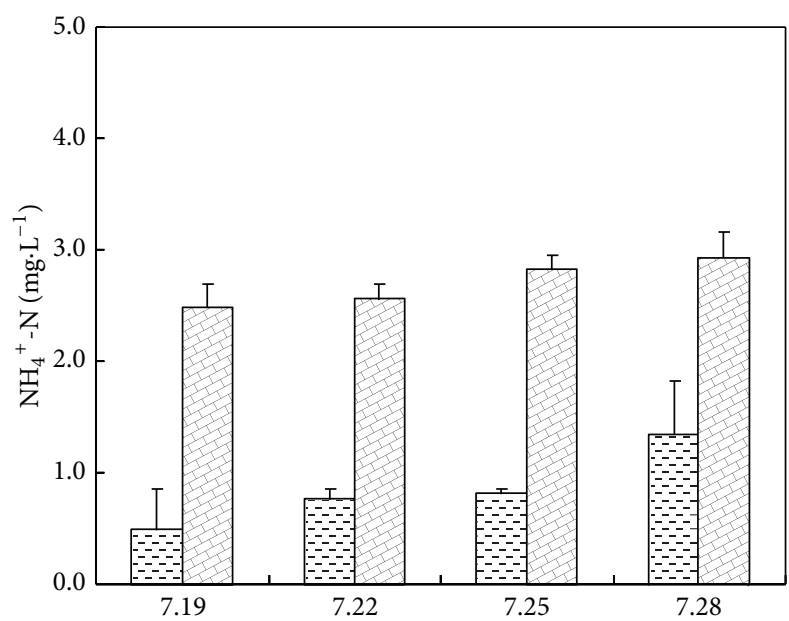

田 CK

因 1

(a)

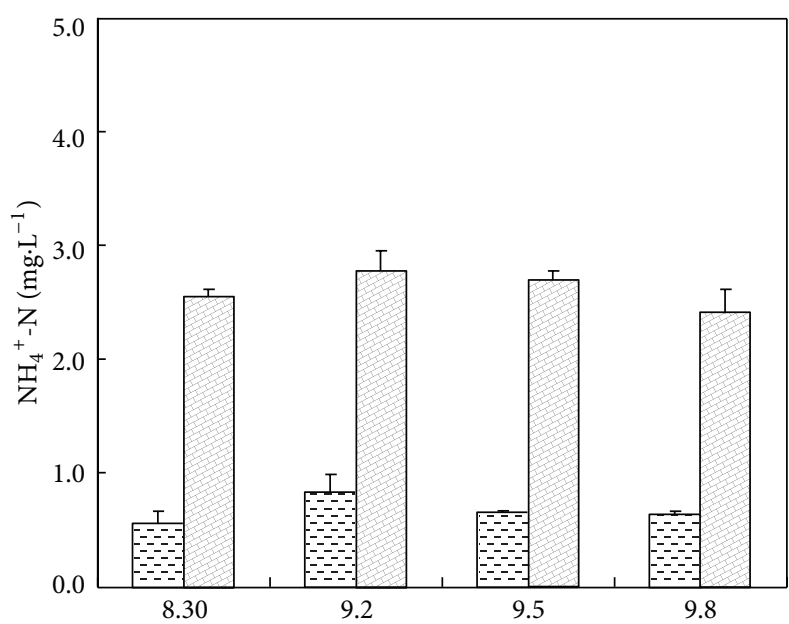

$\mathrm{G}$ CK

回 $\mathrm{T} 3$

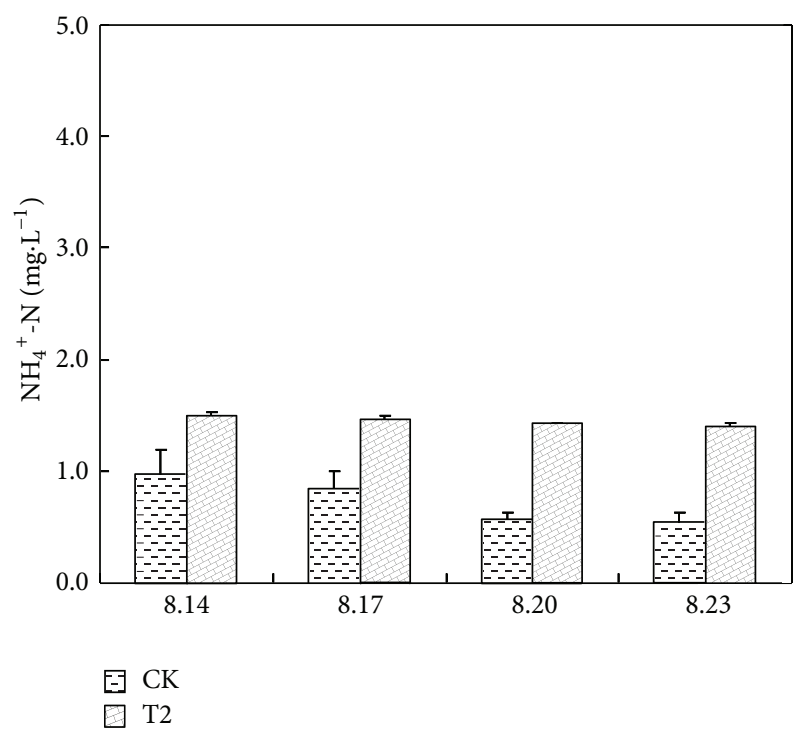

(b)

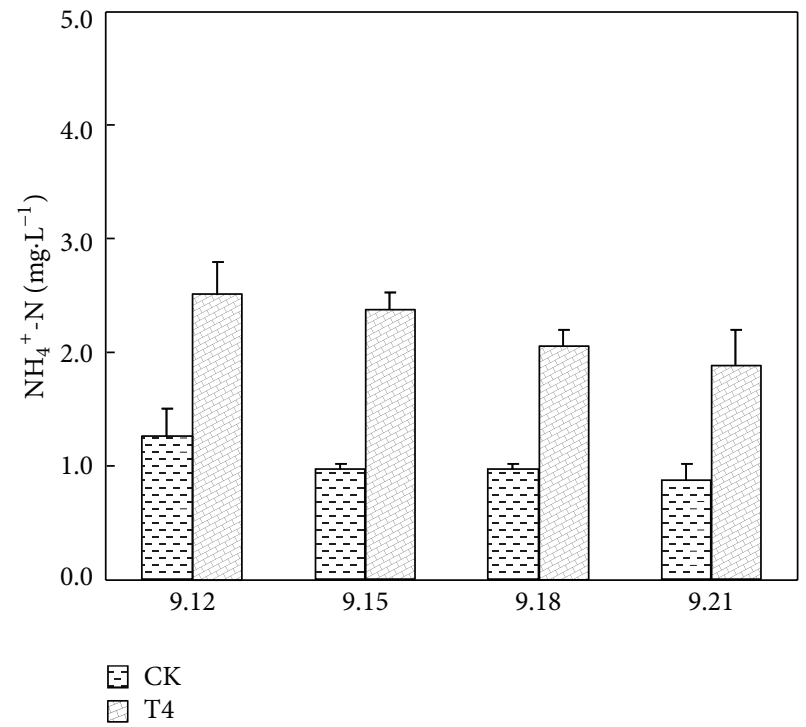

(d)

FIGURE 3: The change of the concentration of $\mathrm{NH}_{4}{ }^{+}-\mathrm{N}$ during submergence in 2010. CK indicates alternate drying and wet irrigation; T1, T2, $\mathrm{T} 3$, and T4 denote the submergence at tillering stage, jointing-booting stage, panicle initiation stage, and milky stage, respectively. Vertical bars represent \pm standard error (SE) of the mean.

The various forms of $\mathrm{N}$, caused by the actions of microorganisms, are dependent on temperature and time. The subsequent movement of nitrate is dependent on the presence of water in excess of field capacity. This timing should correspond with the plant's need for N. Logically, placement of N into the soil profile as a fertilizer addition would ideally be as close to the time that a plant needs the nutrient as possible to minimize the chance for loss into the environment. In this experiment, we observed that urea fertilization can significantly increase the concentration of $\mathrm{NH}_{4}{ }^{+}-\mathrm{N}$ and $\mathrm{TN}$ but has a little influence on $\mathrm{NO}_{3}{ }^{-}-\mathrm{N}$.

The major nitrogen treatment mechanisms of rice paddy include microbial interactions with nitrogen, sedimentation, chemical adsorption, and plant uptake [22]. In traditional nitrogen treatments, the biological nitrogen transition requires a two-step process: nitrification followed by denitrification. Nitrification implies a chemolithoautotrophic oxidation of ammonia to nitrate under strict aerobic conditions. The nitrification process is very oxygen demanding. During the submergence, the biological denitrification mechanism makes use of nitrate as the terminal electron acceptor in low-oxygen environments [23]. Under CID condition, the concentrations of $\mathrm{NH}_{4}{ }^{+}-\mathrm{N}$ at four stages were higher than that of $\mathrm{NO}_{3}{ }^{-}-\mathrm{N}$. As is shown in Table $3, \mathrm{NH}_{4}{ }^{+}-\mathrm{N}$ was the major component of $\mathrm{N}$ in runoff water after submergence. Similar results were also reported in paddy soil in Southern 


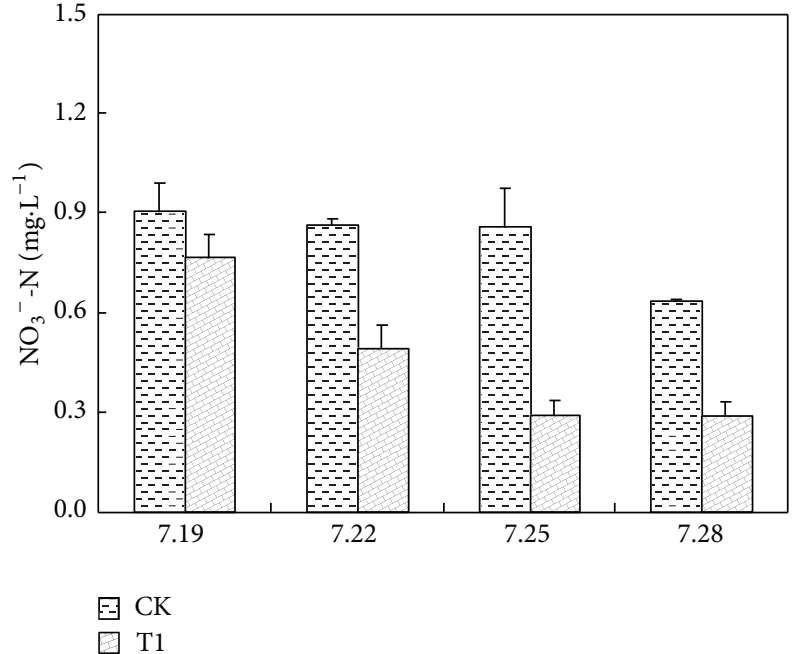

(a)

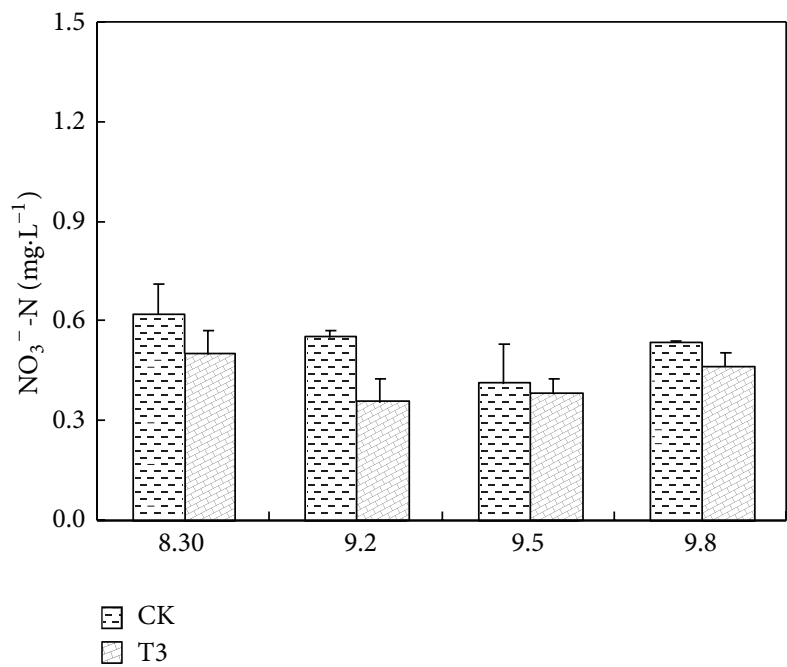

(c)

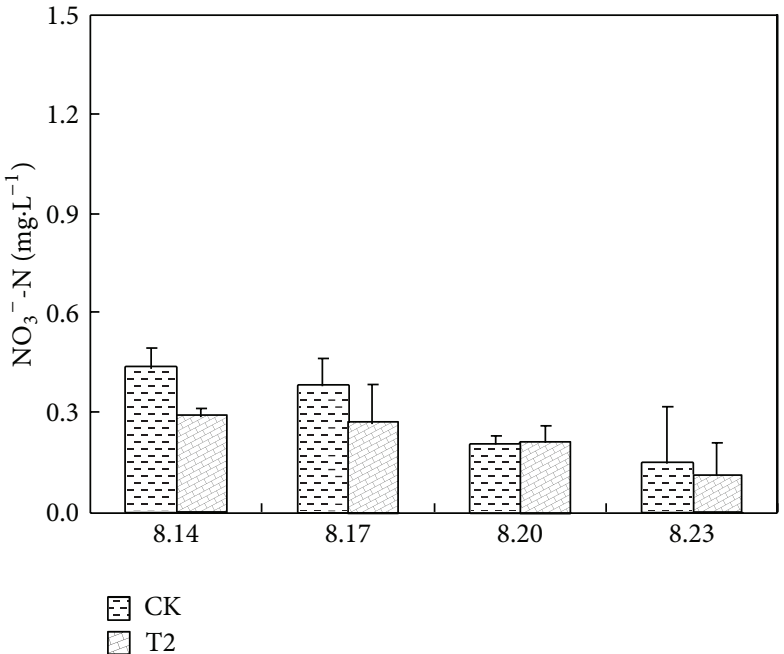

(b)

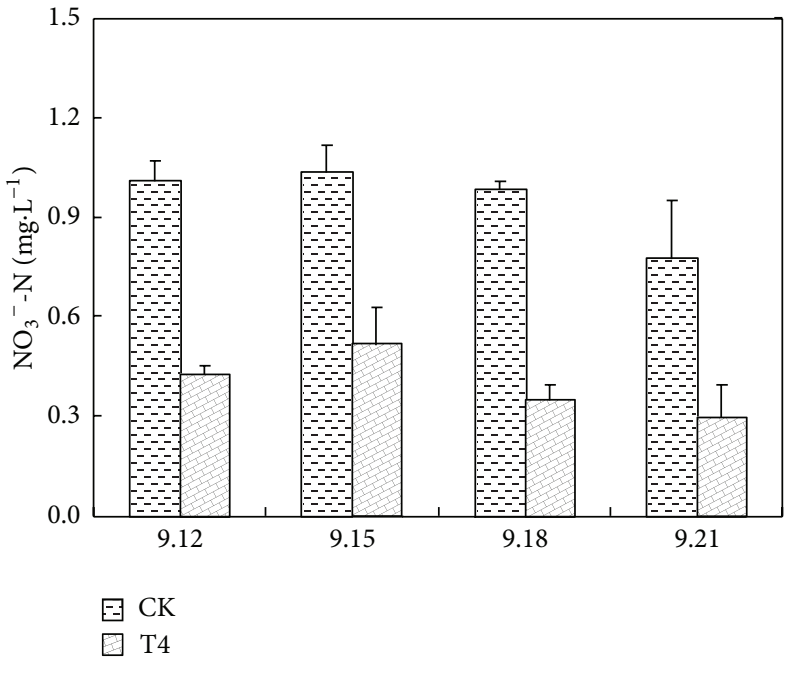

(d)

FIGURE 4: The change of the concentration of $\mathrm{NO}_{3}{ }^{-}-\mathrm{N}$ during submergence in 2010. CK indicates alternate drying and wet irrigation; T1, T2, T3, and T4 denote the submergence at tillering stage, jointing-booting stage, panicle initiation stage, and milky stage, respectively. Vertical bars represent \pm standard error (SE) of the mean.

TABLE 3: Nitrogen loss by runoff during the period of submergence in 2010.

\begin{tabular}{lcccccccc}
\hline \multirow{2}{*}{ Form of $\mathrm{N}$} & \multicolumn{2}{c}{ Tillering stage } & \multicolumn{2}{c}{ Jointing-booting stage } & \multicolumn{2}{c}{ Panicle initiation stage } & \multicolumn{2}{c}{ Milky stage } \\
& $\mathrm{T} 1$ & $\mathrm{CK}$ & $\mathrm{T} 2$ & $\mathrm{CK}$ & $\mathrm{T} 3$ & $\mathrm{CK}$ & $\mathrm{T} 4$ & $\mathrm{CK}$ \\
\hline $\mathrm{NH}_{4}{ }^{+}-\mathrm{N}(\mathrm{g} / \mathrm{ha})$ & $124 \pm 6.8$ & $520 \pm 24.7$ & $294 \pm 13.1$ & $1207 \pm 50.3$ & $520 \pm 30.6$ & $973 \pm 52.2$ & $77 \pm 3.9$ & $672 \pm 28.6$ \\
$\mathrm{NO}_{3}{ }^{-}-\mathrm{N}(\mathrm{g} / \mathrm{ha})$ & $36 \pm 2.1$ & $214 \pm 10.2$ & $42 \pm 5.3$ & $485 \pm 19.8$ & $84 \pm 4.8$ & $910 \pm 43.8$ & $30 \pm 1.8$ & $196 \pm 9.3$ \\
\hline
\end{tabular}

Note: CK indicates alternate drying and wet irrigation; T1, T2, T3, and T4 denote the submergence at tillering stage, jointing-booting stage, panicle initiation stage, and milky stage, respectively. Each value is the mean $\pm \mathrm{SD}(n=3)$.

China [24]. This is because the nitrification was suppressed by lack of oxygen due to prolonged submergence. The concentration of $\mathrm{NH}_{4}{ }^{+}-\mathrm{N}$ in surface water at tillering stage is higher than that at the following three stages. This is because the growth is strong at jointing-booting and panicle initiation stages, which lead to the reduction of $\mathrm{NH}_{4}{ }^{+}-\mathrm{N}$ and $\mathrm{NO}_{3}{ }^{-}-\mathrm{N}$.
Generally, nitrogen loss through drainage increases as $\mathrm{N}$ rate and runoff volume increase, especially as $\mathrm{N}$ rates are greater than the economic optimum. CID had been shown to decrease water flow [25] and thus supports results from this study. Compared to CK, the CID treatment significantly decreases the loss of $\mathrm{NH}_{4}{ }^{+}-\mathrm{N}$ and $\mathrm{NO}_{3}{ }^{-}-\mathrm{N}$, indicating that 
$\mathrm{NH}_{4}{ }^{+}-\mathrm{N}$ and $\mathrm{NO}_{3}{ }^{-}-\mathrm{N}$ loads in the runoff were not only correlated with runoff volume but also pertinent to $\mathrm{NH}_{4}{ }^{+}-\mathrm{N}$ and $\mathrm{NO}_{3}{ }^{-}-\mathrm{N}$ concentrations during given runoff events.

This study only investigated the potential of CID at single stage for reducing nitrogen emission from rice paddies in Southern China. It did not investigate the effect of CID at the compound stages and the multistages and change of $\mathrm{N}$ after submergence withdrawal. More research needs to be carried out in the future to define these relationships.

\section{Conclusions}

In Southern China, the water quality in paddy is easily affected by various forms of $\mathrm{N}$. The high rates of $\mathrm{N}$ application generally resulted in high concentrations of $\mathrm{NH}_{4}{ }^{+}-\mathrm{N}$ and TN in the surface water on the second day indicating the period with the highest risk of $\mathrm{N}$ runoff. Compared to $\mathrm{CK}$, the concentration of $\mathrm{NO}_{3}{ }^{-}-\mathrm{N}$ in surface water showed some reduction under CID at four stages but differed largely among the treatments. $\mathrm{NH}_{4}{ }^{+}-\mathrm{N}$ was the major component of $\mathrm{N}$ in runoff water after submergence at four stages. Consistent with the reduction of drainage, $\mathrm{CID}$ at four stages can significantly decrease the amount of $\mathrm{NO}_{3}{ }^{-}-\mathrm{N}$ and $\mathrm{NH}_{4}{ }^{+}-\mathrm{N}$ losses by runoff in relation to $\mathrm{CK}$. The study can be helpful for water level management in rice paddy with compromise of water saving, reduction of $\mathrm{N}$, and high yield.

\section{Conflict of Interests}

The authors declare that there is no conflict of interests regarding the publication of this paper.

\section{Acknowledgments}

This work was funded by Key Program granted by the National Nature \& Science Foundation of China (nos. 51479063, 51279059, and 41271236) and supported by the Supporting Program of the "Outstanding Young Creative Talents in Hohai University," "Outstanding Scientific and Technological Innovation Team in Jiangsu Colleges and Universities," and "the Priority Academic Program Development of Jiangsu Higher Education Institutions." The authors extend their gratitude to editor and the anonymous reviewers for substantial comments on earlier versions of this paper.

\section{References}

[1] R. W. Skaggs, D. Amatya, R. O. Evans, and J. E. Parsons, "Characterization and evaluation of proposed hydrologic criteria for wetlands," Journal of Soil and Water Conservation, vol. 49, no. 5, pp. 501-510, 1994.

[2] G. W. Randall and J. A. Vetsch, "Nitrate losses in subsurface drainage from a corn-soybean rotation as affected by fall and spring application of nitrogen and nitrapyrin," Journal of Environmental Quality, vol. 34, no. 2, pp. 590-597, 2005.

[3] N. Chirinda, J. E. Olesen, J. R. Porter, and P. Schjønning, "Soil properties, crop production and greenhouse gas emissions from organic and inorganic fertilizer-based arable cropping systems,"
Agriculture, Ecosystems \& Environment, vol. 139, no. 4, pp. 584594, 2010.

[4] K. Wang, R. D. Zhang, and H. Chen, "Drainage-process analyses for agricultural non-point-source pollution from irrigated paddy systems," Journal of Irrigation and Drainage Engineering, vol. 140, Article ID 04013004, pp. 1-14, 2014.

[5] P. Belder, B. A. M. Bouman, R. Cabangon et al., "Effect of watersaving irrigation on rice yield and water use in typical lowland conditions in Asia," Agricultural Water Management, vol. 65, no. 3, pp. 193-210, 2004.

[6] B. A. M. Bouman, "A conceptual framework for the improvement of crop water productivity at different spatial scales," Agricultural Systems, vol. 93, no. 1-3, pp. 43-60, 2007.

[7] B. A. M. Bouman, E. Humphreys, T. P. Tuong, and R. Barker, "Rice and water," Advances in Agronomy, vol. 92, pp. 187-237, 2007.

[8] G. Shao, J. Cui, S. Yu et al., "Impacts of controlled irrigation and drainage on the yield and physiological attributes of rice Impacts of controlled irrigation and drainage on the yield and physiological attributes of rice," Agricultural Water Management, vol. 149, pp. 156-165, 2015.

[9] K. Surajit and D. De, Principles and Practices of Rice Production, John Wiley \& Sons, New York, NY, USA, 1981.

[10] C.-G. Lee, T. D. Fletcher, and G. Sun, "Nitrogen removal in constructed wetland systems," Engineering in Life Sciences, vol. 9, no. 1, pp. 11-22, 2009.

[11] Y. Takai and T. Kamura, "The mechanism of reduction in waterlogged paddy soil," Folia Microbiologica, vol. 11, no. 4, pp. 304-313, 1966.

[12] V. Lalonde, C. A. Madramootoo, L. Trenholm, and R. S. Broughton, "Effects of controlled drainage on nitrate concentrations in subsurface drain discharge," Agricultural Water Management, vol. 29, no. 2, pp. 187-199, 1996.

[13] D. Hesterberg, B. de Vos, and P. A. C. Raats, "Chemistry of subsurface drain discharge from an agricultural polder soil," Agricultural Water Management, vol. 86, no. 1-2, pp. 220-228, 2006.

[14] M. X. Huang, S. Zhang, Y. J. Tang, and B. X. Chen, "Nitrogen losses from farm runoff under simulated rainfall conditions," Soil and Environmental Sciences, vol. 10, no. 1, pp. 6-10, 2001.

[15] I. Wesström and I. Messing, "Effects of controlled drainage on N and $\mathrm{P}$ losses and $\mathrm{N}$ dynamics in a loamy sand with spring crops," Agricultural Water Management, vol. 87, no. 3, pp. 229-240, 2007.

[16] R. O. Evans, R. W. Skaggs, and J. W. Gilliam, "Controlled versus conventional drainage effects on water quality," Journal of Irrigation and Drainage Engineering, vol. 121, no. 4, pp. 271276, 1995.

[17] G. W. Randall and D. J. Mulla, "Nitrate nitrogen in surface waters as influenced by climatic conditions and agricultural practices," Journal of Environmental Quality, vol. 30, no. 2, pp. 337-344, 2001.

[18] Y.-Q. Zhang, M.-X. Wen, X.-P. Li, and X.-J. Shi, "Long-term fertilisation causes excess supply and loss of phosphorus in purple paddy soil," Journal of the Science of Food and Agriculture, vol. 94, no. 6, pp. 1175-1183, 2014.

[19] X. Guo, J. Yuan, F. Guo, and Z. Chen, "Preliminary study on water-catching and controlled irrigation technology of rice," Transactions of the Chinese Society of Agricultural Engineering, vol. 25, no. 4, pp. 70-73, 2009. 
[20] S. E. Yu, Z. M. Miao, W. G. Xing, G. C. Shao, and Y. X. Jiang, "Research advance on irrigation and drainage for rice by using field water level as regulation index," Journal of Irrigation and Drainage, vol. 29, pp. 134-136, 2010 (Chinese).

[21] J. E. Ayars, E. W. Christen, and J. W. Hornbuckle, "Controlled drainage for improved water management in arid regions irrigated agriculture," Agricultural Water Management, vol. 86, no. 1-2, pp. 128-139, 2006.

[22] N. R. Khatiwada and C. Polprasert, "Assessment of effective specific surface area for free water surface constructed wetlands," Water Science and Technology, vol. 40, no. 3, pp. 83-89, 1999.

[23] M. Prosnansky, Y. Sakakibara, and M. Kuroda, "High-rate denitrification and SS rejection by biofilm-electrode reactor (BER) combined with microfiltration," Water Research, vol. 36, no. 19, pp. 4801-4810, 2002.

[24] X. J. Hu, X. H. Shao, Y. Y Li, J. He, S. G. Lu, and Y. Qiu, "Effects of controlled and mid-gathering irrigation mode of paddy rice on the pollutants emission and reduction," Energy Procedia, vol. 16, pp. 907-914, 2012.

[25] G.-C. Shao, S. Deng, N. Liu, S.-E. Yu, M.-H. Wang, and D.-L. She, "Effects of controlled irrigation and drainage on growth, grain yield and water use in paddy rice," European Journal of Agronomy, vol. 53, pp. 1-9, 2014. 

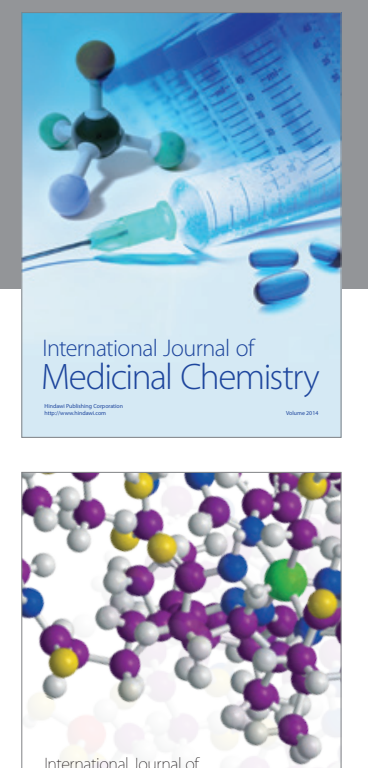

\section{Carbohydrate} Chemistry

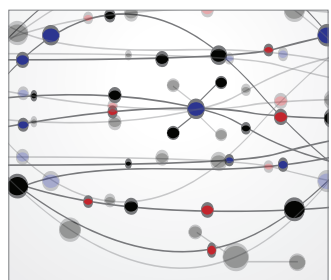

The Scientific World Journal
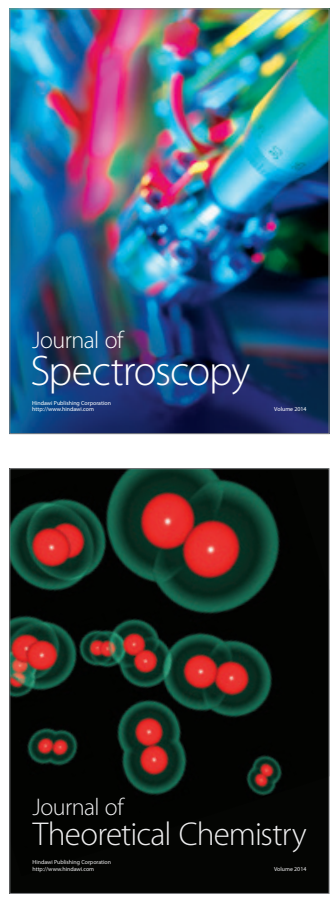
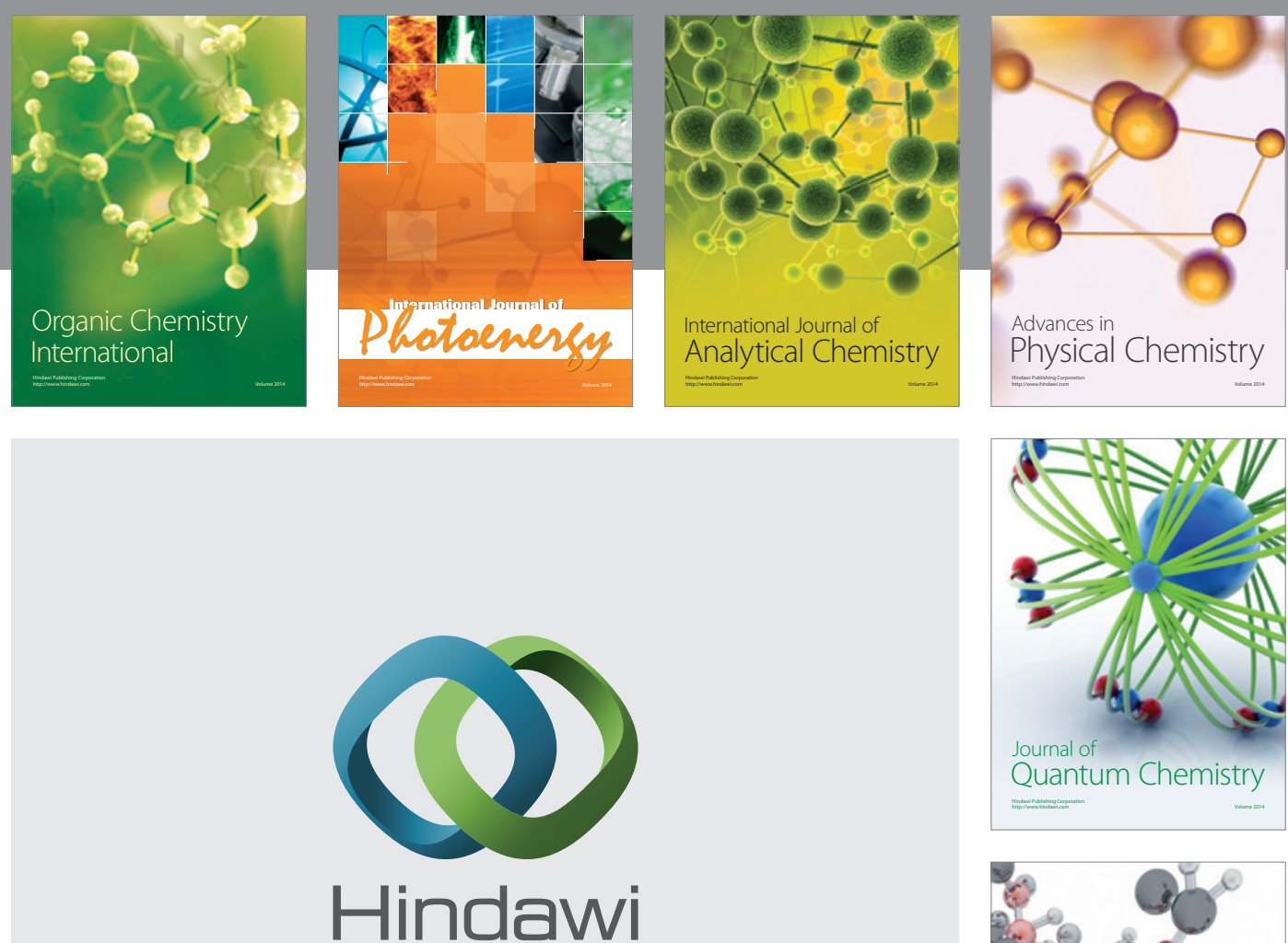

Submit your manuscripts at

http://www.hindawi.com

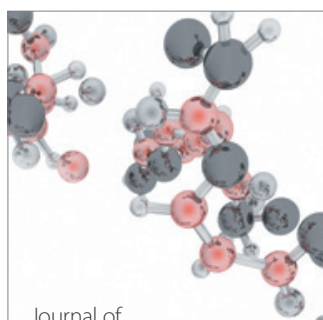

Analytical Methods

in Chemistry

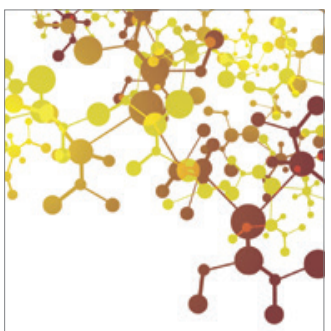

Journal of

Applied Chemistry

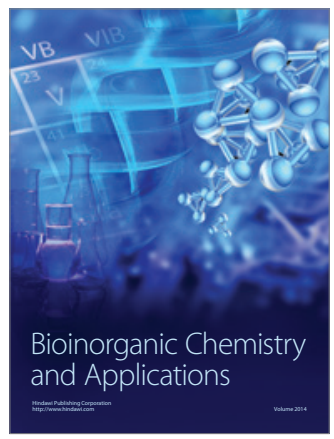

Inorganic Chemistry
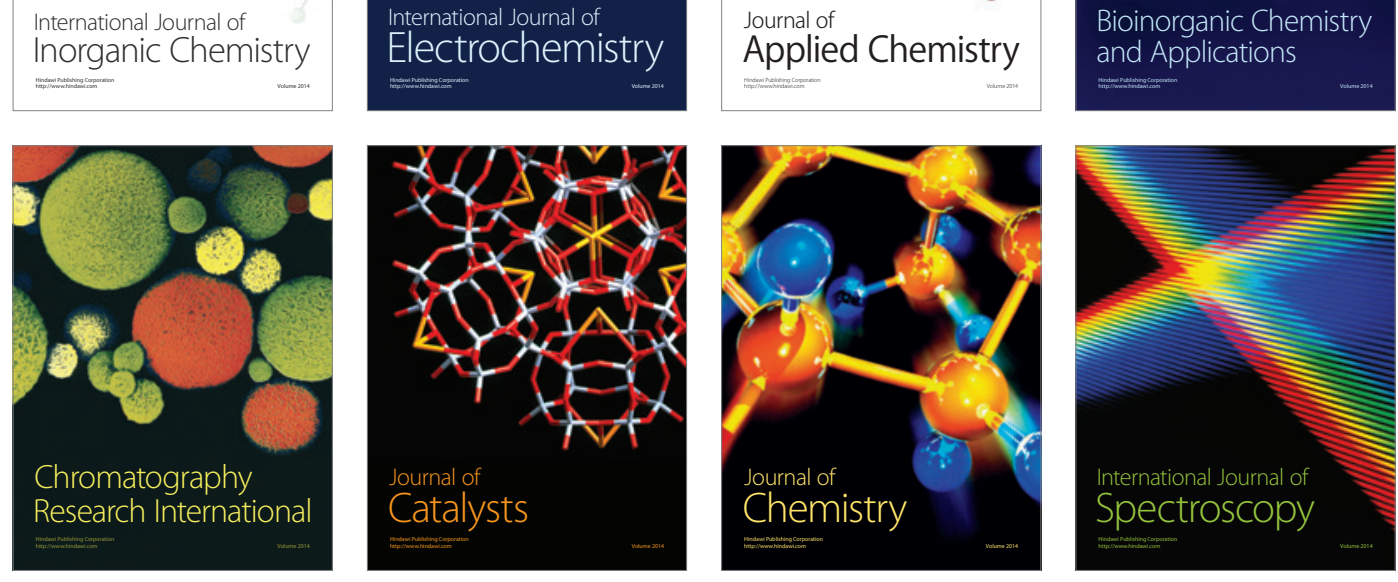